\begin{tabular}{|ccc|}
\hline Jurnal Penelitian dan Evaluasi Pendidikan \\
Volume 22, No 2, December 2018 (197-207)
\end{tabular}

\title{
IMPACT OF ADMISSION TYPE ON STUDENTS' ACHIEVEMENT IN ECONOMY AND BUSINESS SCHOOL OF BATUSANGKAR STATE INSTITUTE OF ISLAMIC STUDIES
}

\author{
David $^{1}$ *, Nasvizar Guspendri ${ }^{1}$ \\ ${ }^{1}$ IAIN Batusangkar
}

${ }^{1}$ Jl. Jend. Sudirman No.137, Limo Kaum, Lima Kaum, Tanah Datar, Sumatera Barat 27217

* Corresponding Author. Email: davidazis@gmail.com

\begin{abstract}
The study is aimed at finding the differences in students' academic achievement based on the admission system type to IAIN Batusangkar and the size of the contribution of admission systems to students' achievement. The study uses the quantitative research approach. The comparative multivariate technique is used for the data analysis. Subjects include 159 student candidates for the local-exam stream, 161 for the national-exam stream, and 123 for the achievement-based stream. Findings show that there is a significant difference in academic achievement between students admitted through the achievement stream and students admitted through the local and national-exam streams. There is no significant difference between the local-exam system and the national-exam system. The contribution of admission systems over academic achievement is 5.4\%; specified: $5.2 \%$ for Semester I, 2.3\% for Semester II, 3.8\% for Semester III, $4.1 \%$ for Semester IV, and $4.4 \%$ for Semester V.
\end{abstract}

Keywords: university admission system, entrance examination, academic achievement

Permalink/DOI: bttp://dx.doi.org/10.21831/pep.v22i2.22367 


\section{Introduction}

The student selection system in the university is aimed at grouping candidates who are qualified to be accepted and who are not. Accepted candidates are predicted to be able to finish the education program without much difficulty. Declined candidates are those who are predicted to have a lot of difficulty in finishing the education program. There are at least four things to consider in the student entrance system; namely: (1) prediction effectiveness, (2) economic efficiency, (3) teaching-learning inventive, and (4) equity (Suryabrata, 2004). Accuracy in pre-diction is the ability of the screening instrument to be able to predict that the accepted students will be successful in their classes. Economic efficiency is integrated in the prediction effectiveness in knowing whether, by increasing fund, time, and effort, it will be worthwhile in terms of the prediction (social benefit and cost). In the equality aspect, equal opportunity is given to those who register.

Further, Suryabrata (2004) stated that selection results will group candidates into four categories: (1) those are predicted to be successful and are successful; (2) those who are predicted to fall short will fall short; (3) those are predicted to be successful but fail; and (4) those who are predicted to fail but actually make it. If 1 and 2 happen, it will not be a problem; however, if it is 3 and 4, this will raise problems. In the case of 3 and 4 , the prediction is said to be positively deficient or negative prediction. In order to minimalize negative prediction, Suryabrata suggested six alternatives: (1) success criteria, (2) treatment strategy, (3) candidate origin, (4) kind and number of predictors, (5) technique for combining the predictors, and (6) technique for determining passing grades. A selection system functions effectively when the predictors function well. This will happen if the instruments are valid. Further up, Mardapi (1993) stated university entrances selection system needs instruments to measure candidates' qualifications, one of which is a test that is valid and reliable.
Instrument validity, as explained by Allen \& Yen (1979), is the accuracy of the instrument in its measurement function. Meanwhile, Azwar (2007) stated that stated that validity can be explained by how far an $\mathrm{X}$ observed score can detect its pure $\mathrm{T}$ score. A score may not be identical with its real score; they can be identical when the test is valid, complete without errors. In other words, validity is related to how far an instrument measures what it is supposed to measure. In addition, an instrument must be able to give a picture of how accurate the data are. By accuracy is meant that an instrument must be able to depict the smallest differences among the subjects (Mardapi, 2008). Whether or not an instrument is valid substantially depends on the measurement objective. Validity is not applicable for all; an instrument may be valid for one objective but not for another. As it has been stated by Cronbach (1984), an instrument that is valid for one decision making may not be as valid for another and for another group.

In terms of its estimation, for both the characteristics and functions of a test, Azwar (2007b) categorized validity into three types: (1) content validity, (2) construct validity, and (3) criterion-related validity. Content validity answers the question how far the test items cover all the domains of contents, objects, or situations being measured. Analysis of content validity does not involve statistics, but expert judgement. Content validity is categorized into two types: face validity and logical validity. Face validity places emphases on appearance. Face validity is achieved when each test item measures a relevant aspect and the underlying principle is common sense. Construct validity shows how far an instrument measures the theoretical constructs of what is supposed to be measured. Construct validity looks at how far the scores resulting from the measurement reflect the theoretical constructs that underline the development of the instrument. To measure construct validity, complex statistical analyses are needed such as factor analysis and multi-trait multi-method analysis. Criterion-related validity is based on criteria; i.e. 
it is detected by the relation between the scores of the test and the scores of the criteria. Suryabrata (2004) stated criterionrelated validity is divided into two types: concurrent validity and predictive validity. Concurrent validity is obtained by using the test scores as a predictor and the scores of another test as a criterion in the same time. Correlation between these two score types gives concurrent validity.

Besides being valid, an instrument must be reliable. Reliability refers to how far the instrument and results of the measurement are trusty. Measurement results are trusty if, in a number of measurement on the same subjects, the results are relatively the same (Suryabrata, 2005). Reliability, according to Mehrens (1980), is the degree of consistency between two measurements on the same subjects. Furthermore, Allen \& Yen (1979) refer to reliability as a condition wherein the observed scores have a high correlation with the actual scores. Reliability has two concepts: internal consistency and stability reliability. Internal consistency involves one-time testing, known as single-trial administration, while stability reliability refers to two score groups, results of two test administrations, using the same, or identical, test on the same subjects but at different times (Mardapi, 2008). Further on, Surapranata (2006) stated that there are at least four concepts of reliability: parallel or equivalent, test-retest, split-half, and internal consistency.

Different screening objectives use different instruments. The university selection instrument is aimed at predicting that accepted candidates will not have difficulties in finishing their study. Student candidates registering into IAIN Batusangkar in the academic year 2013 were selected by way of three streams (1) local, (2) national, and (3) academic achievement. Local admission is done by way of written tests and interviews conducted solely by IAIN Batusangkar. The preparation of the test instruments, administering of the tests, and issuance of results were done by the university. For the national stream, the test instruments were prepared by the central committee; the administering of the test by the local committee. Meanwhile, for the academic achievement stream, selection was done since students were still in the high school by using scores in the report cards. In the present time, these three admission systems are known as (1) Academic Achievement Selection of Islamic State University (SPAN-PTKIN), (2) Entrance Examination of Islamic State University (UM-PTKIN), and (3) Local Screening. However, since the used data are those of the 2013 students, the old names are used. All the three admission systems have the same objective in admitting candidates who are predicted to be successful and rejecting the ones who are predicted to fail. It is a fact, however, that there is no information, up to the present time, which among the three modes of selection is the better one seen from the academic achievement of the students during their study in the university. Thus, the present study is conducted under the title of the impact of the selection types on the academic achievement of students of the Islamic Economy and Business, IAIN Batusangkar.

\section{Method}

In view of the nature of the data and the way the data were obtained, it can be said that the study is ex-post facto research. No manipulation or treatment was given to the research variables. Ex post facto research, as stated by Kartowagiran (1998), is one that tries to reveal the impact of a variable with no manipulation that may obstruct the genuine cause-effect relation of the variables.

The study took place in IAIN Batusangkar, and the gathered data were students' academic achievement (GPA) of the 2013 academic year, semesters I, II, III, IV, and V. The study was conducted in four months. The study used multivariate analysis of variance (MANOVA) as the data analysis technique, with generalized randomized block design (GRB-p) suggested by Kirk (1995). The design of the comparison of academic achievements can be seen in Table 1.

Impact of Admission Type on Students' Achievement in ... -

David, Nasvizar Guspendri 
Table 1. Comparison Design of Students' Academic Achievement among Local, National and Achievement

\begin{tabular}{lcccccc}
\hline \multirow{2}{*}{$\begin{array}{l}\text { Admission } \\
\text { Stream }\end{array}$} & \multicolumn{6}{c}{ Grade Point Average } \\
\cline { 2 - 7 } Local (1) & $\mathrm{X}_{1}$ & $\mathrm{X}_{2}$ & $\mathrm{X}_{3}$ & $\mathrm{X}_{4}$ & $\mathrm{X}_{5}$ & $\mathrm{X}_{6}$ \\
\hline & $\mathrm{X}_{111}$ & $\mathrm{X}_{112}$ & $\mathrm{X}_{113}$ & $\mathrm{X}_{114}$ & $\mathrm{X}_{115}$ & $\mathrm{X}_{116}$ \\
& $\mathrm{X}_{211}$ & $\mathrm{X}_{212}$ & $\mathrm{X}_{213}$ & $\mathrm{X}_{214}$ & $\mathrm{X}_{215}$ & $\mathrm{X}_{216}$ \\
& Etc. & Etc. & Etc. & Etc. & Etc. & Etc. \\
& $\mathrm{X}_{121}$ & $\mathrm{X}_{122}$ & $\mathrm{X}_{123}$ & $\mathrm{X}_{124}$ & $\mathrm{X}_{125}$ & $\mathrm{X}_{126}$ \\
National (2) & $\mathrm{X}_{221}$ & $\mathrm{X}_{222}$ & $\mathrm{X}_{223}$ & $\mathrm{X}_{224}$ & $\mathrm{X}_{225}$ & $\mathrm{X}_{226}$ \\
& $\mathrm{Etc.}$ & Etc. & Etc. & Etc. & Etc. & Etc. \\
& $\mathrm{X}_{131}$ & $\mathrm{X}_{132}$ & $\mathrm{X}_{133}$ & $\mathrm{X}_{134}$ & $\mathrm{X}_{135}$ & $\mathrm{X}_{136}$ \\
Achievement(3) & $\mathrm{X}_{231}$ & $\mathrm{X}_{232}$ & $\mathrm{X}_{233}$ & $\mathrm{X}_{234}$ & $\mathrm{X}_{135}$ & $\mathrm{X}_{236}$ \\
& Etc. & Etc. & Etc. & Etc. & Etc. & Etc. \\
\hline
\end{tabular}

Notes

$\mathrm{X}_{1}=$ IP Semester 1

Admission Stream

$\mathrm{X}_{2}=$ IP Semester 2

$1=$ Local

$\mathrm{X}_{3}=$ IP Semester 3

$2=$ National

$\mathrm{X}_{4}=$ IP Semester 4

$3=$ Achievement

$\mathrm{X}_{5}=$ IP Semester 5

$\mathrm{X}_{6}=$ Grade Point Average

\section{Findings and Discussion}

Findings

The general findings can be divided into two: descriptive and inferential. These can be presented as follows.

\section{Descriptive Data}

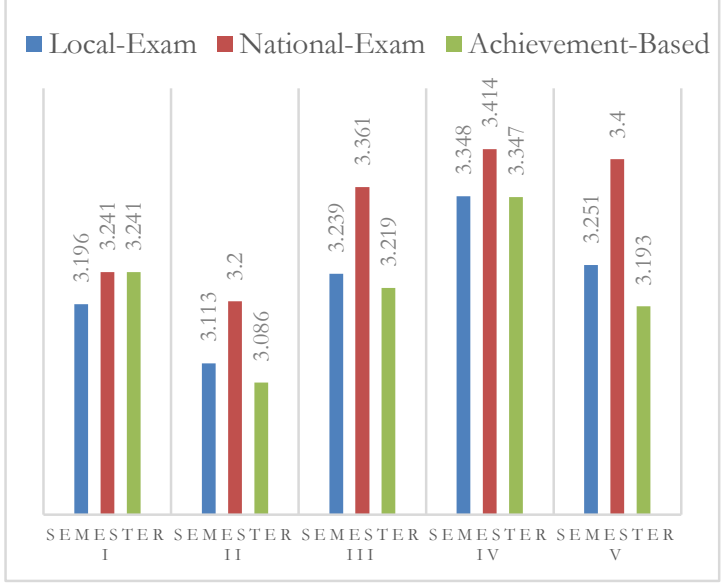

Figure 1. GPA Averages of Students of the Syariah Accounting

Department, Academic Year 2013

In Figure 1, it can be seen that, in each semester, the highest GPA average is owned by students who are admitted through the national stream. The second highest GPA average belongs to the local-stream students. Students who are admitted by way of their school academic achievements have the lowest GPA average. For the local admission system, the lowest GPA average is during Semester I; while in Semesters II to V they are superior to those of students of the third admission type. The data for students of the Syariah Management Department can be seen in Figure 2.

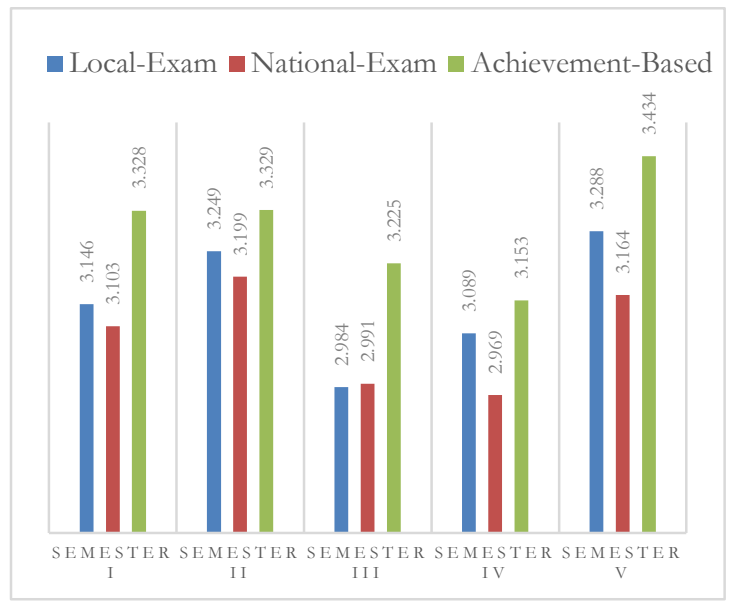

Figure 2. GPA Averages of Students of the Syariab Management

Department, Academic Year 2013

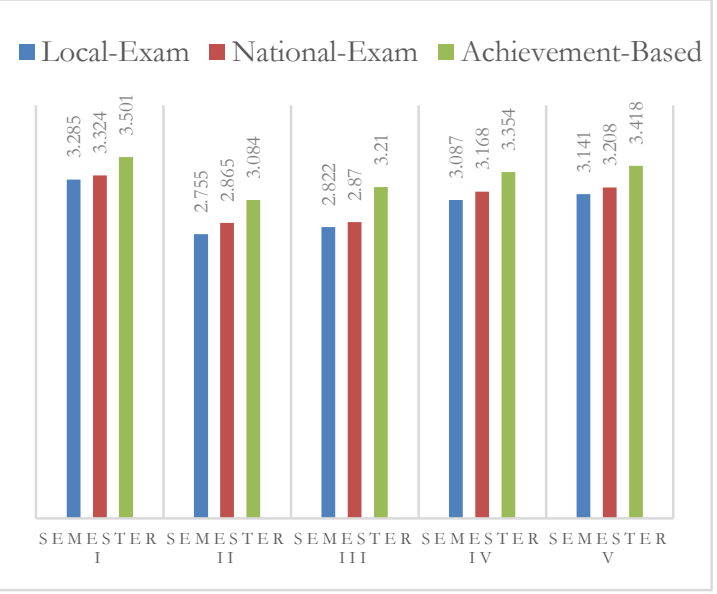

Figure 3. GPA Averages of Students of the Syariah Banking Department, Academic Year 2013

Different from the Syariah Accounting Department, where the highest GPAs are obtained by students of the national admission, in the Syariab Management Department, students of the school achievement admis- 
sion type are superior to other students from Semesters I to V. After this, students of the local admission system follow. Next is the nature of academic achievements of students of the Syariah Banking Department in Figure 3.

For the Syariah Banking Department, the highest GPA average belongs to the achievement-stream students. This is the same as what happens in the Syariab Management Department. Figure 4 presents data of the Informatics Management Department.

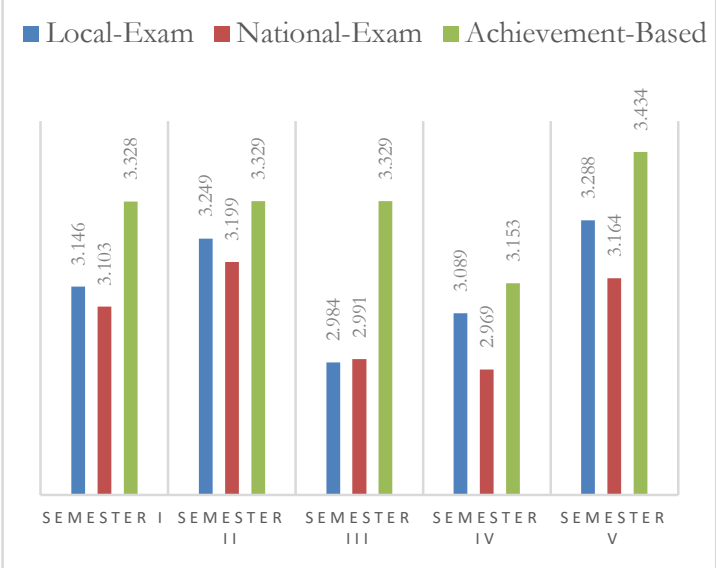

Figure 4. GPA Averages of Students of the Informatics Management Department, Academic Year 2013

In Figure 4, students who are admitted through the school academic achievements have higher achievements than those from both the local and national admission systems throughout the five semesters. Seeing results from the four departments, it turns out that students of the national recruitment system do better in their academic achievements are only in those of the Syariab Accounting Department. For the Departments of Syariab Management, Syariab Banking, and Informatics Management, students who have higher achievements are those who are admitted through the school academic achievement stream. So, based on the data description, it can be seen that there is an impact of the admission types on the students' academic achievements. However, to know whether or not the difference is significant, an analy-sis is conducted that compares the differences among departments and among semesters.

\section{Multivariate Analysis of V ariance (MANOVA)}

An assumption of the =MANOVA is that each dependent variable should have the same variance for all the groups. To test this assumption, the Levene's test is used. Results of the Levene's test can be seen in Table 2 .

Table 2. Levene's Test of Equality of Error Variances

\begin{tabular}{lrrll}
\hline & \multicolumn{1}{c}{$F$} & $d f 1$ & $d f 2$ & sig \\
\hline Semester I & 1.883 & 2 & 440 & .153 \\
Semester II & .533 & 2 & 440 & .587 \\
Semester III & .052 & 2 & 440 & .949 \\
Semester IV & .544 & 2 & 440 & .581 \\
Semester V & 1.041 & 2 & 440 & 3.54 \\
Grade Point Average & .105 & 2 & 440 & .900 \\
\hline
\end{tabular}

The null hypothesis test: Error variance of the dependent variable is equal across groups

\section{a. Design: Intercept $+J M$}

In Table 2, it can be seen that all dependent variables have a significance level higher than 0.05. This means that each dependent variable has the same variance fulfilling the requirement of the MANOVA. Multivariate tests are used to find the differences among students' academic achievements across semesters I, II, III, IV, and V and among the academic achievements of students who are admitted by the three modes of local, national, and achievement. Table 3.

Results of the analyses can be seen in

The multivariate test to know whether each factor has an impact on the dependent variable groups can be done by any of the four multivariate tests for significance; they are Pillai's Trace, Wilks' Lambda, Hotelling's Trace, and Roy's Largest Root. Based on Table 3, it can be seen that the Wilks' Lambda $F=3.562$ and sig. $=0.000$, so that the $\mathrm{H}_{0}$ is rejected meaning that there is a difference in academic achievements among students of semesters I, II, III, IV, and V and in the GPAs among students who are admitted through the modes local, national, and achievement. To know the differences in the students' achievements in each semester among the three recruitment systems, data analysis is presented in Table 4.

Impact of Admission Type on Students' Achievement in ...

David, Nasvizar Guspendri 
Table 3. Multivariate Tests

\begin{tabular}{llccccc}
\hline Effect & & Value & $F$ & Hypothesis $d f$ & Error $d f$ & Sig. \\
\hline Intercept & Pillai's Trace & .993 & $10091.262^{\mathrm{b}}$ & 6.000 & 435.000 & .000 \\
& Wilks' Lambda & .007 & $10091.262^{\mathrm{b}}$ & 6.000 & 435.000 & .000 \\
& Hotelling's Trace & 139.190 & $10091.262^{\mathrm{b}}$ & 6.000 & 435.000 & .000 \\
& Roy's Largest Root & 139.190 & $10091.262^{\mathrm{b}}$ & 6.000 & 435.000 & .000 \\
$\mathrm{JM}$ & Pillai's Trace & .093 & 3.555 & 12.000 & 872.000 & .000 \\
& Wilks' Lambda & .909 & $3.562^{\mathrm{b}}$ & 12.000 & 870.000 & .000 \\
& Hotelling's Trace & .099 & 3.568 & 12.000 & 868.000 & .000 \\
& Roy's Largest Root & .070 & $5.091 \mathrm{c}$ & 6.000 & 436.000 & .000 \\
\hline
\end{tabular}

a. Design: Intercept + JM c. The statistic is an upper bound on $F$ that yields a lower bound on

b. Exact statistic the significance level

Table 4. Tests of Between-Subjects Effects

\begin{tabular}{|c|c|c|c|c|c|c|}
\hline Source & Dependent Variable & $\begin{array}{c}\text { Type III Sum } \\
\text { of Squares }\end{array}$ & $d f$ & Mean Square & $F$ & Sig. \\
\hline Corrected & Semester I & $2.253^{\mathrm{a}}$ & 2 & 1.126 & 12.009 & .000 \\
\hline \multirow[t]{5}{*}{ Model } & Semester II & $1.512^{\mathrm{b}}$ & 2 & .756 & 5.073 & .007 \\
\hline & Semester III & $3.340^{c}$ & 2 & 1.670 & 8.798 & .000 \\
\hline & Semester IV & $2.298^{\mathrm{d}}$ & 2 & 1.149 & 9.294 & .000 \\
\hline & Semester V & $2.316^{\mathrm{e}}$ & 2 & 1.158 & 10.012 & .000 \\
\hline & Grade Point Average & $2.451^{\mathrm{f}}$ & 2 & 1.226 & 12.485 & .000 \\
\hline \multirow[t]{6}{*}{ Intercept } & Semester I & 4699.200 & 1 & 4699.200 & 50099.666 & .000 \\
\hline & Semester II & 4218.383 & 1 & 4218.383 & 28296.248 & .000 \\
\hline & Semester III & 4228.578 & 1 & 4228.578 & 22276.030 & .000 \\
\hline & Semester IV & 4595.648 & 1 & 4595.648 & 37180.221 & .000 \\
\hline & Semester V & 4605.016 & 1 & 4605.016 & 39815.163 & .000 \\
\hline & Grade Point Average & 4469.043 & 1 & 4469.043 & 45524.328 & .000 \\
\hline \multirow{6}{*}{ JM } & Semester I & 2.253 & 2 & 1.126 & 12.009 & .000 \\
\hline & Semester II & 1.512 & 2 & .756 & 5.073 & .007 \\
\hline & Semester III & 3.340 & 2 & 1.670 & 8.798 & .000 \\
\hline & Semester IV & 2.298 & 2 & 1.149 & 9.294 & .000 \\
\hline & Semester V & 2.316 & 2 & 1.158 & 10.012 & .000 \\
\hline & Grade Point Average & 2.451 & 2 & 1.226 & 12.485 & .000 \\
\hline \multirow[t]{6}{*}{ Error } & Semester I & 41.271 & 440 & .094 & & \\
\hline & Semester II & 65.595 & 440 & .149 & & \\
\hline & Semester III & 83.524 & 440 & .190 & & \\
\hline & Semester IV & 54.386 & 440 & .124 & & \\
\hline & Semester V & 50.890 & 440 & .116 & & \\
\hline & Grade Point Average & 43.194 & 440 & .098 & & \\
\hline \multirow[t]{6}{*}{ Total } & Semester I & 4789.900 & 443 & & & \\
\hline & Semester II & 4332.029 & 443 & & & \\
\hline & Semester III & 4351.165 & 443 & & & \\
\hline & Semester IV & 4697.794 & 443 & & & \\
\hline & Semester V & 4706.235 & 443 & & & \\
\hline & Grade Point Average & 4558.086 & 443 & & & \\
\hline Corrected & Semester I & 43.524 & 442 & & & \\
\hline \multirow[t]{5}{*}{ Total } & Semester II & 67.107 & 442 & & & \\
\hline & Semester III & 86.864 & 442 & & & \\
\hline & Semester IV & 56.684 & 442 & & & \\
\hline & Semester V & 53.206 & 442 & & & \\
\hline & Grade Point Average & 45.645 & 442 & & & \\
\hline
\end{tabular}

a. $R$ Squared $=.052($ Adjusted $R$ Squared $=.047)$

d. $R$ Squared $=.041$ (Adjusted $R$ Squared $=.036)$

b. $R$ Squared $=.023$ (Adjusted $R$ Squared $=.018$ )

e. $R$ Squared $=.044($ Adjusted $R$ Squared $=.039)$

c. $R$ Squared $=.038$ (Adjusted $R$ Squared $=.034)$

f. R Squared $=.054($ Adjusted R Squared $=.049)$ 
Table 5. Summary of the Results of Analysis of Differences in Students' Achievements

\begin{tabular}{llrrcc}
\hline No & \multicolumn{1}{c}{ Achievement } & $F$ & Sig. & Decision & $\begin{array}{c}\text { Contribution of Recruitment } \\
\text { Type on Achievement }\end{array}$ \\
\hline 1 & Semester I & 12.009 & .000 & $\mathrm{H}_{0}$ rejected & $5.2 \%$ \\
2 & Semester II & 5.073 & .007 & $\mathrm{H}_{0}$ rejected & $2.3 \%$ \\
3 & Semester III & 8.798 & .000 & $\mathrm{H}_{0}$ rejected & $3.8 \%$ \\
4 & Semester IV & 9.294 & .000 & $\mathrm{H}_{0}$ rejected & $4.1 \%$ \\
5 & Semester V & 10.012 & .000 & $\mathrm{H}_{0}$ rejected & $4.4 \%$ \\
6 & GPA & 12.485 & .000 & $\mathrm{H}_{0}$ rejected & $5.4 \%$ \\
\hline
\end{tabular}

Table 6. Multiple Comparisons

\begin{tabular}{|c|c|c|c|c|c|}
\hline Dependent Variable & (I) Stream & (J) Stream & $\begin{array}{c}\text { Mean Difference } \\
(\mathrm{I}-\mathrm{J})\end{array}$ & Std. Error & Sig. \\
\hline \multirow[t]{6}{*}{ Semester I } & \multirow[t]{2}{*}{ Local } & National & -.0138 & .03424 & .922 \\
\hline & & Achievement & $-.1656^{*}$ & .03678 & .000 \\
\hline & \multirow[t]{2}{*}{ National } & Local & .0138 & .03424 & .922 \\
\hline & & Achievement & $-.1519^{*}$ & .03668 & .000 \\
\hline & \multirow[t]{2}{*}{ Achievement } & Local & $.1656^{*}$ & .03678 & .000 \\
\hline & & National & $.1519^{*}$ & .03668 & .000 \\
\hline \multirow[t]{6}{*}{ Semester II } & \multirow[t]{2}{*}{ Local } & National & -.0425 & .04317 & .617 \\
\hline & & Achievement & $-.1455^{*}$ & .04636 & .008 \\
\hline & \multirow[t]{2}{*}{ National } & Local & .0425 & .04317 & .617 \\
\hline & & Achievement & -.1030 & .04624 & .085 \\
\hline & \multirow[t]{2}{*}{ Achievement } & Local & $.1455^{*}$ & .04636 & .008 \\
\hline & & National & .1030 & .04624 & .085 \\
\hline \multirow[t]{6}{*}{ Semester III } & \multirow[t]{2}{*}{ Local } & National & .0040 & .04871 & .997 \\
\hline & & Achievement & $-.1918^{*}$ & .05232 & .001 \\
\hline & \multirow[t]{2}{*}{ National } & Local & -.0040 & .04871 & .997 \\
\hline & & Achievement & $-.1958^{*}$ & .05218 & .001 \\
\hline & \multirow[t]{2}{*}{ Achievement } & Local & $.1918^{*}$ & .05232 & .001 \\
\hline & & National & $.1958^{*}$ & .05218 & .001 \\
\hline \multirow[t]{6}{*}{ Semester IV } & \multirow[t]{2}{*}{ Local } & National & .0165 & .03931 & .915 \\
\hline & & Achievement & $-.1517^{*}$ & .04222 & .002 \\
\hline & \multirow[t]{2}{*}{ National } & Local & -.0165 & .03931 & .915 \\
\hline & & Achievement & $-.1683^{*}$ & .04210 & .000 \\
\hline & \multirow[t]{2}{*}{ Achievement } & Local & $.1517^{*}$ & .04222 & .002 \\
\hline & & National & $.1683^{*}$ & .04210 & .000 \\
\hline \multirow[t]{6}{*}{ Semester V } & \multirow[t]{2}{*}{ Local } & National & -.0680 & .03802 & .203 \\
\hline & & Achievement & $-.1822^{*}$ & .04084 & .000 \\
\hline & \multirow[t]{2}{*}{ National } & Local & .0680 & .03802 & .203 \\
\hline & & Achievement & $-.1142^{*}$ & .04073 & .020 \\
\hline & \multirow[t]{2}{*}{ Achievement } & Local & $.1822^{*}$ & .04084 & .000 \\
\hline & & National & $.1142^{*}$ & .04073 & .020 \\
\hline \multirow[t]{6}{*}{ Grade Point Average } & \multirow[t]{2}{*}{ Local } & National & -.0242 & .03503 & .787 \\
\hline & & Achievement & $-.1767^{*}$ & .03762 & .000 \\
\hline & \multirow[t]{2}{*}{ National } & Local & .0242 & .03503 & .787 \\
\hline & & Achievement & $-.1525^{*}$ & .03752 & .000 \\
\hline & \multirow[t]{2}{*}{ Achievement } & Local & $.1767^{*}$ & .03762 & .000 \\
\hline & & National & $.1525^{*}$ & .03752 & .000 \\
\hline
\end{tabular}


Based on Table 4, differences in students' academic achievements are summarized in Table 5. From Table 5, it is known that for every semester, including for grade point averages, the $\mathrm{H}_{0}$ is rejected. This means that, for each semester, there is a difference in academic achievements among students who are admitted by the local, national, and achievement systems. It can therefore be concluded that there is an impact of recruitment systems on students' achievements. In terms of the contribution of recruitment systems on semesters, the highest is on GPA, then Semester I, then Semester $\mathrm{V}$ last.

To further know in more details the differences among the recruitment systems, the Scheffe test is done. The results can be seen in Table 6.

From the results of the multiple comparison calculations, the mean difference between the local and national systems is 0.0138 with a significance 0.922 , between the local and achievement -0.1656 and 0.000 , and between the national and achievement systems 0.1519 and 0.000 . It can be stated that there is a difference in achievements between students of the achievement recruitment and local recruitment and between students of the achievement recruitment and national recruitment. There is no significant difference in achievement between students of the local and national recruitment systems for Semester I. For more detailed pictures, more information on the results of the Scheffe test is presented in Table 7.

Table 7. GPA Average for Semester I

\begin{tabular}{lccc} 
Scheffea,b,c & & & \\
\multirow{2}{*}{ Recruitment Stream } & \multirow{N}{*}{$\mathrm{N}$} & \multicolumn{2}{c}{ Subset } \\
\cline { 3 - 4 } & & 1 & 2 \\
\hline Local & 159 & 3.2223 & \\
National & 161 & 3.2360 & \\
Achievement & 123 & & 3.3879 \\
Sig. & & .929 & 1.000 \\
\hline
\end{tabular}

In terms of the homogenous subset, it can be seen that, for students' GPAs for Semester I, the local and national streams can be one group and the achievement stream stands alone as a different group.
This means that there is no difference in students' achievement for Semester I between the local and national groups. Seen from the averages, it turns out that higher achievements are obtained by students of the achievement recruitment system.

In Table 6, for Semester II, a mean difference of -0.0435 is found between the local and national streams with a significance of 0.617 ; local and achievement streams 0.1455 with a significance of 0.008 ; and national and achievement -0.1030 with a significance of 0.085 . It turns out that differences only occur between the local and achievement groups; no difference between the local and national groups and between the national and achievement groups. This can be seen in Table 8 .

Table 8. GPA Average for Semester II

Scheffea,b,c

\begin{tabular}{lccc}
\hline & & \multicolumn{2}{c}{ Subset } \\
\cline { 3 - 4 } Recruitment Stream & $\mathrm{N}$ & 1 & 2 \\
\hline Local & 159 & 3.0470 & \\
National & 161 & 3.0894 & 3.0894 \\
Achievement & 123 & & 3.1924 \\
Sig. & & .645 & .076 \\
\hline
\end{tabular}

In terms of the homogenous subset, it can be seen that students' achievements for Semester II are categorizable into two groups, however achievements of students of the national group overlap with those of the two other groups. This means that the achievements of the national stream could be one group with those of the local stream and with those of the achievement stream. Seen from the score averages, higher achievements are with students of the achievement system.

As can be seen in Table 6, for Semester III, a mean difference is obtained between the local and national streams $(0.0040)$ with a significance $=0.997$; between the local and achievement streams (-0.1918) with a significance $=0.001$; and between the national and achievement streams (0.1958) with a significance $=0.001$. It can be concluded that there are differences in students' achievements between the local and achievement groups and between the national and 
achievement groups. There is no difference for the local and national groups. This is presented in a summary form as Table 9 .

Table 9. GPA Average for III

Scheffea,b,c

\begin{tabular}{lccc}
\hline \multirow{2}{*}{ Recruitment Stream } & \multirow{2}{*}{$\mathrm{N}$} & \multicolumn{2}{c}{ Subset } \\
\cline { 3 - 4 } & & 1 & 2 \\
\hline Local & 161 & 3.0468 & \\
National & 159 & 3.0508 & \\
Achievement & 123 & & 3.2426 \\
Sig. & & .997 & 1.000 \\
\hline
\end{tabular}

From the homogeneous subsets, it can be seen that the GPAs of students recruited through the national system are in one group with those of the achievement system. From the averages, it turns out that achievements in Semester III are higher with students who are admitted through the school achievement system.

For Semester IV, as can be seen in Table 6 , the local and national groups have a mean difference of 0.0165 with a significance of 0.915; the local and achievement groups 0.1517 with 0,002 ; and the national and achievement groups -0.1683 with 0.000 . There is a difference in the academic achievements of the students who are accepted through the local and achievement systems, and through the national and achievement systems for Semester IV. These differences are further shown in Table 10.

Table 10. GPA Average for Semester IV

\begin{tabular}{|c|c|c|c|}
\hline \multirow{2}{*}{$\begin{array}{l}\text { Recruitment } \\
\text { Stream }\end{array}$} & \multirow{2}{*}{$\mathrm{N}$} & \multicolumn{2}{|c|}{ Subset } \\
\hline & & 1 & 2 \\
\hline Local & 159 & 3.1656 & \\
\hline National & 161 & 3.2336 & \\
\hline Achievement & 123 & & 3.3478 \\
\hline Sig. & & .235 & 1.000 \\
\hline
\end{tabular}

From the homogeneous subsets, it can be seen the academic achievements of Semester $\mathrm{V}$ students from the local and national streams become one group and those of the achievement stream stands alone as a different group. Based on their average score, the students of the achievement re- cruitment system tend to have higher GPAs than those of the other two streams.

Finally, for Semester V, as can be seen in Table 6 , there is a mean difference between the students admitted by the local and national streams by -0.0242 with a significance of 0.787 , between the local and achievement streams by -0.1767 with a significance of 0.000 , and between the national and achievement streams by -0.1525 with a significance of 0.000 . Based on these data, it can be seen that there is a difference between the local and achievement groups and the national and achievement groups. However there is no difference between the local and national groups. For a more detailed picture, this is represented in Table 11.

Table 11. GPA Average for Semester V

\begin{tabular}{lccc} 
Scheffea,b,c & & \\
\hline \multirow{2}{*}{ Recruitment Stream } & \multirow{2}{*}{$\mathrm{N}$} & \multicolumn{2}{c}{ Subset } \\
\cline { 3 - 4 } & & 1 & 2 \\
\hline Local & 159 & 3.1337 & \\
National & 161 & 3.1579 & \\
Achievement & 123 & & 3.310 \\
& & & 4 \\
Sig. & & .805 & 1.000 \\
\hline
\end{tabular}

Seen from the homogeneous subsets, it can be seen that the GPAs of the students of the local and national streams become one group, while those of the achievement stream form a different group. Based on the GPA average scores, the academic achievement of the achievement group is higher than those of the other two groups.

\section{Discussion}

The academic achievement of students admitted by the national recruitment system is higher in the Accounting Department than that in the local and achievement systems. This high achievement occurs in all semesters except for Semester I where there are equal levels. On the contrary, there is a different phenomenon for the other three departments; Syariah Management, Syariah Banking, and Informatics Management. For these three departments, high academic achievement is achieved by students of the 
school achievement system. Up from Semester I through Semester V, students from the achievement stream consistently show higher academic performances. In this recruitment system, the primary consideration is laid on the achievements of the candidates through the scores in the high-school report cards from Grade X to Grade XII. Candidates are nominated by the school, taken from the best ten of the class. Meanwhile, candidates who are admitted through the national or local entrance examinations rely solely on the results of the examination.

From the multiple comparisons of students' GPAs, it can be seen that there are significant differences between the achievement stream and the national and local streams. Meanwhile, there is no significant difference in the GPAs between the national and local streams. The absence of differences in this matter may be caused by the fact that the national and local systems are the same in that they rely solely on the results of the entrance tests. It is different from the school achievement system in which criteria for accepting the candidates are based on the academic achievements of the candidates in their three years of high-school education. It is true that selection is influenced by several factors such as, among others, procedures, motivation, testing contexts, candidates' experiences, scoring methods, and exam supervisors' characteristics (Gregory, 2013). Included in these are validity and reliability of the test items. It has been further proposed by Ghani (2008) that types and autonomy levels have impacts on learning outcomes.

Contribution of the admission system toward GPA is not that high, only $5.4 \%$; to be more specific: $5.2 \%$ for Semester I, $2.3 \%$ for Semester II, 3.8\% for Semester III, 4.1\% for Semester IV, and $4.4 \%$ for Semester V. Stronger influences come from some other different factors. In general, factors affecting achievement can be internal or external. Internal factors include health, psyche, intelligence, attention, interest, talents, maturity, and readiness. Fatigue can also be one. External factors include family, school, and society (Slameto, 2010). A study by Waluyo
(2006) shows that learning styles and approaches have impacts on learning outcomes. Finally, teachers' evaluation techniques and instruments can also influence learning achievements; considering that the instruments used by the teacher may not have been valid and reliable.

\section{Conclusion}

Based on the results of the multivariate statistical analyses, it is found that there is a significant difference in the students' academic achievements between those admitted by the school achievement recruitment stream and those admitted by the national or local entrance examinations. In another fact, there is no significant difference in the academic achievement between students who are accepted through the national examination stream and those who are accepted through the local examination stream. The GPAs of students of the achievement system are higher than GPAs of students of the national and local systems through Semesters I to V. Contribution of the admittance type towards students' GPAs is $5.4 \%$; to be more specific: $5,2 \%$ for Semester I, 2.3\% for Semester II, 3.8\% for Semester III, $4.1 \%$ for Semester IV, and $4.4 \%$ for Semester $V$.

In view of the research findings, it is suggested that university admission systems have more say for the achievement-based recruitment method added with considerations of the candidates' performances during their three-year educational processes in the high school. Since the contribution of admission systems towards academic achievement is not so high, it is also suggested that sufficient attention be given to students' instructional processes after being admitted to study in the university.

\section{Daftar Pustaka}

Allen, M. J., \& Yen, W. M. (1979). Introduction to measurement theory. Monterey, CA: Brooks/Cole Publishing Company. 
Azwar, S. (2007a). Dasar-dasar psikomentri. Yogyakarta: Pustaka Pelajar.

Azwar, S. (2007b). Reliabilitas dan validitas. Yogyakarta: Pustaka Pelajar.

Cronbach, L. J. (1984). Essentials of psychological testing (5th ed.). New York: Harper Dayan.

Ghani, A. R. A. (2008). Pengaruh tes formatif dan kemandirian belajar terhadap hasil belajar Ekonomi siswa SMA. Jurnal Penelitian Dan Evaluasi Pendidikan, 12(2). Retrieved from https://journal.uny.ac.id/index.php/jp ep/article/view/1425

Gregory, R. J. (2013). Tes psikologi: sejarah, prinsip, dan aplikeasi. Jakarta: Erlangga.

Kartowagiran, B. (1998). Pengenalan metode penelitian eksperimen dan ex post facto. In Penataran Berbagai Pendekatan dan Metode Penelitian (p. 7). Yogyakarta: Lemlit IKIP Yogyakarta.

Kirk, R. E. (1995). Experimental design: procedures for the behavioral sciences. New York: International Thomson Publishing Inc.

Mardapi, D. (1993). Daya prediksi tes masuk IKIP Jakarta terbadap prestasi dan lama studi mahasiswa Pascasarjana KPK IKIP Yogyakarta. Yogyakarta.

Mardapi, D. (2008). Teknik penyusunan instrumen tes dan nontes. Yogyakarta:
Mitra Cendikia Press.

Mehrens, W. A. (1980). Measurement and evaluation in education and psychology. Forth Worth: Holt, Rinerhart, and Winston, Inc.

Slameto. (2010). Belajar dan faktor-faktor yang mempengarubi. Jakarta: Rineka Cipta.

Surapranata, S. (2006). Analisis, validitas, reliabilitas dan interpretasi hasil tes, implementasi kurikulum 2004. Bandung: PT. Remaja Rosdakarya.

Suryabrata, S. (2004). Pengembangan sistem seleksi calon mahasiswa perguruan tinggi yang akurat dan berkeadilan. In Seminar Nasional Rekayasa Sistem Penilaian dalam Rangka Meningkatkan Kualitas Pendidikan (p. 3). Yogyakarta: Himpunan Evaluasi Pendidikan Indonesia (HEPI).

Suryabrata, S. (2005). Pengembangan alat ukur psikologis. Yogyakarta: Penerbit Andi.

Waluyo, W. (2006). Pengaruh pendekatan konstruktivistik dan gaya belajar siswa terhadap prestasi belajar Kimia siswa kelas I semester 2 SMA Negeri 1 Ngaglik Sleman tahun pelajaran 2003/2004. Jurnal Penelitian Dan Evaluasi Pendidikan, 8(1). Retrieved from https://journal.uny.ac.id/index.php/jp ep/article/view/2016 